\title{
US DOLLAR AND EURO AS GLOBAL CURRENCIES
}

\author{
Halina Nakonieczna-Kisiel, Prof. \\ Faculty of Economics and Management \\ University of Szczecin \\ Mickiewicza 64, 71-101 Szczecin \\ e-mail:mikmakhz@wneiz.pl
}

Received 15 December 2008, Accepted 9 July 2009

\begin{abstract}
The paper is aimed at presenting the extent to which dollar and euro fulfil particular functions of world money. At the beginning, the author presents theoretical discussion about functions that money should perform in order to be universally used by foreign entities in trade and international finance. Then, the degree to which dollar and euro functioned as world money in the period $1999-2007$ is subject to verification. Finally, dollar and euro prospects for becoming international currencies are discussed.
\end{abstract}

Keywords: world money, functions of world money, dollar, euro, measure of value, currency, means of accumulation.

JEL classification: F31. 


\section{Introduction}

Towards the end of the $18^{\text {th }}$ century gold and silver were used as "currencies" in international trade. The UK pound sterling was the first national currency to become the dominant currency in international transactions, and it remained highly relevant until the World War I, even though the UK economy had lost is leading position to the United States. The reason was that the market players had become accustomed to the "old" rules of behaviour and a well-developed infrastructure in international transactions with a history of over 100 years, which was based on the pound sterling ${ }^{1}$.

The US dollar was first used on a global scale after the World War II. The delay was related to the effects of the Great Crisis and warfare. The US dollar has played the leading role ever since even though since the 1960s we have been witnessing new competitors enter and leave the market, with the German mark being the first of them, followed by the Japanese yen and other currencies (including the IMF's SDR). The role of new national currencies in international settlements has grown mainly after the year 1971 when the United States terminated the convertibility of the dollar to gold. The increased potential of Western European economies, however, resulting from a growing number of member states in their commonwealth and its spectacular success in the currency integration have undermined the role of the US dollar, mainly in favour of the euro although to a much less extent than expected.

The aim of this study is to discuss the individual functions of the US dollar and the euro as global currencies. The analysis is preceded, however, by a presentation of theoretical aspects of the functions which an international currency has to perform to become widely used by foreign entities in international trade and finance. Next - based on the statistical data available - the use of both currencies in the private and official spheres are verified for the years 1999-2007 for each function of the global currency. At the end of the paper, the prospects of the two currencies in their roles of international currencies are described.

\section{Functions of a global currency}

The literature on the subject distinguishes three basic functions which a national currency needs to perform in order to become an international currency ${ }^{2}$ : a measure of value, a legal tender, a means of accumulation. 
A currency performs its first role, a measure of value, in the private sphere when it is used in: setting the prices of goods and services in international exchange, invoicing in international trade, denominating financial instruments and valuing the labour force (e.g. in the form of hourly rates which vary between individual countries). Among all the above areas of application, the use of national currency as invoicing currency of international trade is the most relevant one since it determines to a large extent the demand for the international currency in its other functions. In the official sphere, a given currency is considered a measure of value if it is used by monetary authorities of various countries to define exchange rates thus becoming a reference currency.

A global currency can serve as a legal tender in either of two ways: direct or indirect. In the first case it means that: in the private sphere - exporters and importers use this currency to settle their mutual accounts receivable and payable, and in the official sphere - monetary authorities of individual countries use this currency to cover their imbalance of payments. In an indirect way, on the other hand, the currency performs its function as a legal tender when in the private sphere it serves as the so-called "vehicle currency" while converting one currency into another in the foreign exchange market to settle transactions in trade, and when in the official sphere it is used by central banks to undertake interventions in currency markets in order to either maintain the desired exchange rate or prevent its excessive volatility.

The global currency used in payments for goods and services and in conversions of currencies is known as a settlement (payment) currency. In the international trade, the currency in which an invoice has been issued is also assumed to be the payment currency.

The global currency acts as a means of accumulation if business entities from various countries tend to accumulate financial assets denominated in this currency thus enabling their cross-border transfers. It means that private entities keep their monetary assets in this currency, which is then called an investment (or deposit) currency, and the official monetary authorities accumulate their foreign exchange reserves in that currency, which thus becomes a reserve currency.

The investments made by private entities have usually the form of accumulating financial resources denominated in this currency on banking accounts, and purchasing securities denominated in it. While investing, the entities mentioned make decisions based mainly on profitability but also on a belief that they will have no problems to use their savings in international settlements. Central banks, on the other hand, when accumulating their foreign exchange reserves, pay more attention to liquidity and safety rather then profitability of their savings. 
The above discussed functions of a global currency are interrelated since - as already mentioned - the first one determines the other two. A given national currency cannot be a means of accumulation unless it is earlier used in invoicing. The selection of the invoicing currency, on the other hand, usually determines the payment currency. Its wider use in international trade as a payment currency raises its attractiveness in the eyes of business entities and monetary authorities which tend to accumulate their surpluses (savings) in that currency to ensure liquidity in all the settlements with abroad or to undertake currency interventions. The interrelations between the functions of the global currency and the types of currencies present in international exchange of goods and services have been presented in Figure 1.

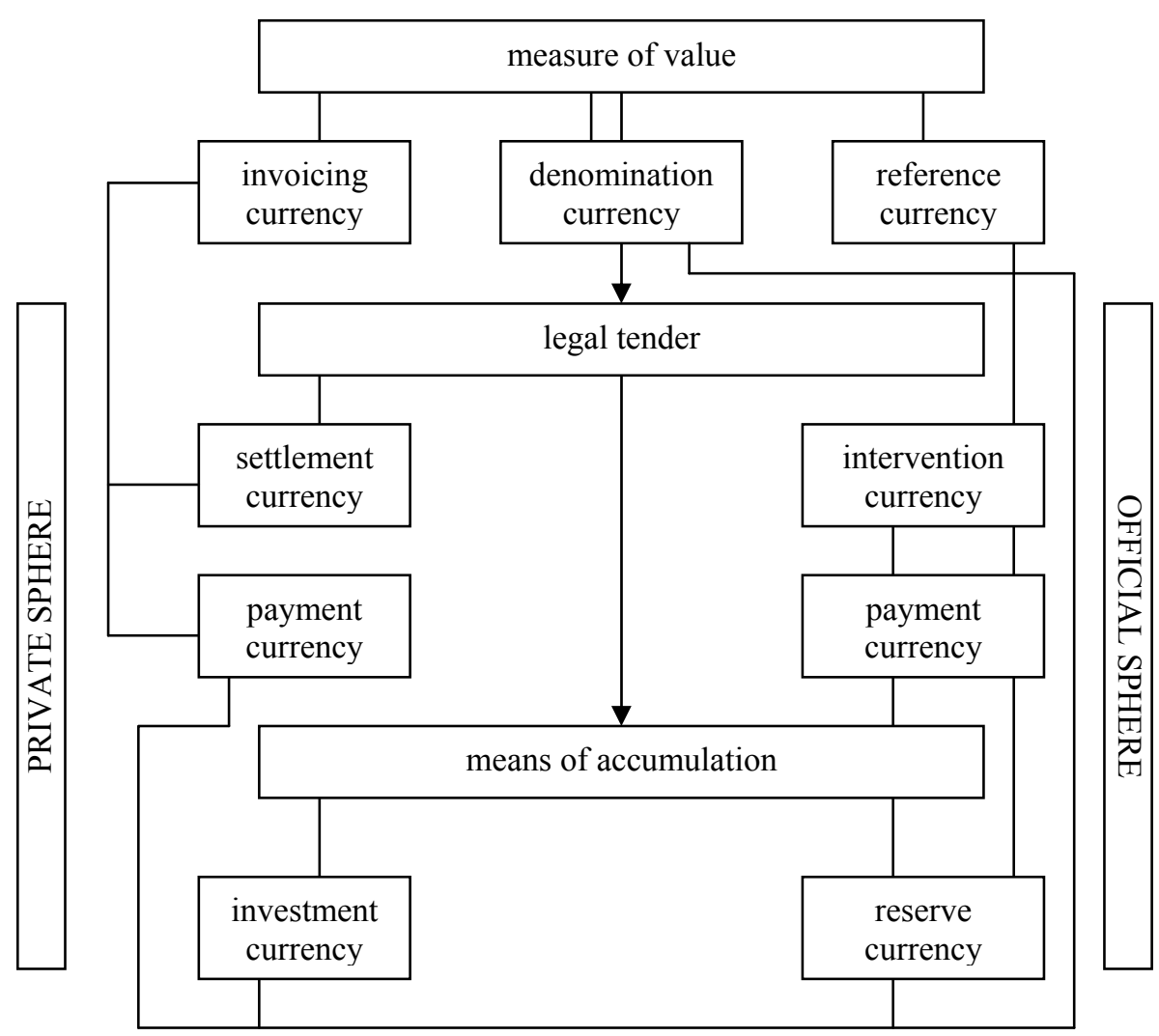

Fig. 1. Interrelations between the functions of the global currency and the types of currencies Source: own study.

\section{The use of the US dollar and euro as measures of value}

The US dollar has always been the most important invoicing currency in international trade. In the early $21^{\text {st }}$ century more than half of invoices in the world exports were denominated in this currency, i.e. as many as in the mid- $1970 \mathrm{~s}^{3}$. The reasons should be traced 
back not only to the US leading position in the global economy, the size and high liquidity of the American financial market and a relatively high political stability of that country but also the habits inherent in international trade such as the sole use of the US dollar in invoicing of international trade in oil, major mineral resources, agricultural produce and aircrafts.

The role of the euro as invoicing currency, however, has been growing, which should be related mainly to the development of the euro area, and the EU enlargement. Although in 2007 the US dollar still kept its top position in invoicing in the foreign trade of: the US (90\% of imports), Asia (approx. $80 \%$ of exports and $76 \%$ of imports), Africa (75\% of exports), Canada (70\% of exports) and the euro area in its transactions with non-EU partners, i.e. third countries (nearly $56 \%$ of imports - see: Table 1), the euro was much more relevant than the US dollar in the transactions between the euro area with non-euro area countries, including both EU member states and other countries. In the year in question approx. 57\% of exports and $51 \%$ of imports was invoiced in the euro. This currency was even more popular in the EU member states which did not belong to the euro area - nearly $59 \%$ of their exports and $57 \%$ of their imports was invoiced in euro. The euro was also the invoicing currency of choice for in exports from the euro area to non-EU countries (nearly $50 \%$ as compared to $44 \%$ reported for the US dollar), and imports of the African countries (nearly 53\%).

The difference in the use of the euro and the US dollar in invoicing in the trade between the euro area and non-EU countries is related - as already mentioned - to the US dollar's dominant role in the world imports of natural resources. The use of the euro rather than the US dollar in Africa's imports, on the other hand, results from various forms of preference in trade and economic cooperation between the former colonies in this part of the world and their European metropolises.

Table 1. The US dollar and the euro invoicing in international trade in 2007 (as \%)

\begin{tabular}{|l|r|r|r|r|}
\hline \multirow{2}{*}{ Part of the world } & \multicolumn{2}{|c|}{ Exports of goods } & \multicolumn{2}{c|}{ Imports of goods } \\
\cline { 2 - 5 } & USD & \multicolumn{1}{c|}{ EUR } & \multicolumn{1}{c|}{ USD } & \multicolumn{1}{c|}{ EUR } \\
\hline Euro area - non-euro area countries & 31.5 & 56.7 & 40.2 & 50.7 \\
\hline $\begin{array}{l}\text { Euro area - third countries } \\
\text { (non-EU countries) }\end{array}$ & 44.0 & 49.7 & 55.7 & 35.2 \\
\hline Non-euro area EU member states & 20.9 & 58.8 & 25.2 & 57.4 \\
\hline United States & & & 90.3 & 2.0 \\
\hline Canada & 70.0 & & & \\
\hline Asia & 80.1 & 5.3 & 76.4 & 5.2 \\
\hline Africa & 75.5 & 23.3 & & 52.9 \\
\hline
\end{tabular}

${ }^{\mathrm{a}}$ both EU member states and third countries.

Source: European Central Bank (www.ecb.int). 
From the viewpoint of the euro's development as a global currency, its use as an invoicing currency in transactions with non-EU countries is of the highest relevance. The author's considerations so far have revealed that for the total euro area the average share of the common currency in invoicing of the exports to third countries is only ca. 5 percentage points higher than the figure for the US dollar. It should be mentioned that the figures for individual euro area countries varied significantly.

In 2006 the majority of export invoices denominated in the euro were issued in Austria (more than 13 percentage points above the euro area average), Italy, Spain and the Netherlands (approx. 4 percentage points above the average for each). The lowest share of the euro invoicing was observed for the Greek and Luxembourgian exports (approx. 21 and 20 percentage points below the euro area average, respectively). Portugal, Ireland, Finland and France, too, noted below-average levels, with their figures ranging from 1 to 6 percentage points below the average (see Table 2).

The euro area's imports from non-EU countries, on the other hand, was dominated as already mentioned - by the US dollar, in which in 2006 as much as 20 percentage points more invoices were issued than in the euro. The use of the US dollar in invoicing was extremely high in the case of the Greek and Dutch imports (approx. 24 and 20 percentage points above the euro area average, respectively).

Table 2. The US dollar and the euro invoicing in international foreign trade of the euro area countries with non-EU countries in 2006 (as \%)

\begin{tabular}{|l|r|r|r|r|}
\hline \multirow{2}{*}{ Country } & \multicolumn{2}{|c|}{ Exports } & \multicolumn{2}{c|}{ Imports } \\
\cline { 2 - 5 } & USD & EUR & USD & \multicolumn{1}{c|}{ EUR } \\
\hline Austria & 23.4 & 62.9 & 27.3 & 60.9 \\
\hline Belgium & 36.9 & 50.0 & 41.8 & 46.3 \\
\hline Finland & 47.6 & 44.0 & 62.8 & 29.6 \\
\hline France & 50.5 & 43.2 & 60.3 & 32.9 \\
\hline Greece & 70.7 & 28.1 & 80.0 & 18.0 \\
\hline Spain & 43.4 & 53.6 & 54.4 & 44.2 \\
\hline Netherlands & 42.1 & 52.5 & 76.3 & 23.4 \\
\hline Ireland & 50.1 & 46.6 & 69.3 & 19.4 \\
\hline Luxembourg & 68.0 & 29.6 & 52.3 & 33.5 \\
\hline Germany & - & - & 40.3 & 40.9 \\
\hline Portugal & 47.2 & 48.9 & 52.1 & 43.4 \\
\hline Italy & 43.4 & 53.7 & 69.8 & 27.5 \\
\hline Euro area total & 44.0 & 49.7 & 55.7 & 35.2 \\
\hline
\end{tabular}

Source: European Central Bank (www.ecb.int).

This phenomenon resulted from a high share of oil and mineral resources in the imports of the euro area, and in the case of the Netherlands - from its high involvement in the imports of oil, resold later to other EU member states ${ }^{4}$. The least extent of the US dollar 
invoicing was observed for imports from non-EU countries in Austria, Germany and Belgium (as much as 28, 15 and 14 percentage points below the euro area average, respectively). In Spain, Luxembourg and Portugal, on the other hand, the use of the US dollar in invoicing of imports was only slightly lower than the euro area average (see Table 2).

In this context it should be mentioned that the new EU member states noted the greatest use of the euro in invoicing of their foreign trade. In 2007 the number of invoices issued in the euro in their exports was nearly three times as high as that of invoices issued in the US dollar; for imports the relationship between the two numbers was slightly worse $-2: 1$. In 2006 the euro was used in invoicing of as much as $73 \%$ of exports and $63 \%$ of imports, whereas five years earlier, both shares were estimated at $57 \%{ }^{5}$. The scale of the euro invoicing in the foreign trade of the other new EU member states which do not belong to the euro area has been shown in Table 3. Even though there are significant differences between individual countries, in each one the euro has become the most important invoicing currency for both exports and imports in the second half of the current decade.

The second major area of use of both currencies, the US dollar and the euro, in their function as a measure of value is to define the exchange rate parity. It is determined by the exchange rate regimes in which those currencies serve as either individual reference currencies or constitute a basket of currencies to which a given country's national currency is pegged.

The choice of an appropriate exchange rate regime belongs to the most important decisions made by monetary authorities of a country since it determines indirectly the size and structure of foreign exchange reserves essential to ensure flawless operation of the system ${ }^{6}$.

Table 3. The share of the euro invoicing in foreign trade of new non-euro area EU member states (as \%)

\begin{tabular}{|c|c|c|c|c|}
\hline \multirow{2}{*}{ Country } & \multicolumn{2}{|c|}{ Exports } & \multicolumn{2}{|c|}{ Imports } \\
\hline & 2001 & 2006 & 2001 & 2006 \\
\hline Bulgaria & 48 & 58 & 56 & 59 \\
\hline Czech Republic & 69 & 72 & 67 & 68 \\
\hline Estonia & 54 & 60 & 54 & 56 \\
\hline Lithuania & 28 & 56 & 38 & 54 \\
\hline Latvia & 34 & 55 & 45 & 61 \\
\hline Poland & 57 & 73 & 57 & 63 \\
\hline Romania & 56 & 68 & 61 & 73 \\
\hline
\end{tabular}

Source: ECB (2008).

According to the IMF data ${ }^{7}$, out of 100 countries which as of 1 January 2007 used a variety of exchange rate regimes, 40 employed either the euro as a reference currency or a 
basket of currencies comprising the euro to which their currency was related, whereas the US dollar or a basket of currencies comprising the US\$ were used as a peg by the majority of Asian and both North and South American currencies. It reveals a strong geographic and institutional diversification of both the US dollar and the euro as reference currencies. The data in Table 4 shows that the exchange rate regimes related in various forms with the euro are observed mainly in the non-euro area EU member states, candidate and potential candidate countries, countries (mainly African, Caribbean, and Pacific) under special unilateral preferences, countries which introduced the euroisation (i.e. use the euro, officially or unofficially, in their internal settlements instead of their national currencies) and countries which have entered into an agreement on partnership and cooperation with the European Union.

Polish zloty at the moment is not formally related to the euro in any of the exchange rate regimes presented. In 2009 we intend to join the ERM II, however, which is an initial step in our aspirations to become the member of the euro area in $2012^{8}$. The decision made by the government has been supported mainly by enterprises which recognise the EU as their basic market and source of supply as the introduction of the euro would reduce their foreign exchange risk and related losses ${ }^{9}$.

Table 4. Countries with exchange rate regimes linked to the euro in 2007

\begin{tabular}{|l|l|}
\hline \multicolumn{1}{|c|}{ Country } & \multicolumn{1}{c|}{ Foreign exchange regime } \\
\hline $\begin{array}{l}\text { Denmark, Estonia, Latvia, Lithuania, } \\
\text { Slovakia }\end{array}$ & $\begin{array}{l}\text { European Exchange Rate Mechanism - } \\
\text { ERM II }\end{array}$ \\
\hline Bulgaria, Bosnia and Herzegovina & Currency board \\
\hline Czech Republic, Romania & Managed floating \\
\hline Hungary, Croatia, Macedonia, Serbia & $\begin{array}{l}\text { Peg arrangements with fluctuations band } \\
\text { based exchange rate regime }\end{array}$ \\
\hline Montenegro, Andorra, Kosovo & Unilateral euroisation \\
\hline $\begin{array}{l}\text { Republic of San Marino, Vatican City, } \\
\text { Monaco, French territorial communities }\end{array}$ & Official euroisation \\
\hline $\begin{array}{l}\text { French overseas territories, CFA Franc } \\
\text { Zone, Cape Verde, Comoros }\end{array}$ & $\begin{array}{l}\text { Peg arrangements based exchange rate } \\
\text { regime }\end{array}$ \\
\hline $\begin{array}{l}\text { Russian Federation, Lithuania, Morocco, } \\
\text { Seychelles, Botswana, Tunisia, Vanuatu }\end{array}$ & $\begin{array}{l}\text { Stable exchange rate regime related to } \\
\text { the SDR and other currency baskets } \\
\text { comprising the euro }\end{array}$ \\
\hline
\end{tabular}

Source: based on the ECB (2007).

\section{The US dollar and the euro in the function of a legal tender}

The above-discussed use of the US dollar and the euro in invoicing of foreign trade provides evidence for their significant role in direct payments of the private sphere. It is widely known that invoicing currency in the international trade of goods and services 
becomes at the same time the payment (settlement) currency. To sum up the earlier considerations, we can state that the euro is less important as a settlement currency than the US dollar since it is used in this function mainly in the trade of the euro area countries with other EU-related countries (candidate and potential candidate countries, countries enjoying unilateral special preferences, etc.). It indicates that as far as the private sphere is concerned, the use of the euro in the function of a legal tender is observed in a regional and institutional rather than international dimension, which is reserved for the US dollar. The latter currency is used in trade and financial settlements by both Americas and Asia, which is based on the confidence in the dollar's purchasing power.

If we look into indirect payments of the private sphere, the US dollar seems to be unbeatable in the foreign exchange market. Business entities treat it as a vehicle currency - a shift from a currency of a relatively low liquidity to a higher one. In the late 1980s the US dollar was used in as much as $90 \%$ of all foreign exchange transactions in the global market, and its role did not change significantly since the introduction of the euro; in 1999 the US dollar was still used in over $87 \%$ of transactions of this type. Even the depreciation of the US dollar against the euro (by approx. $50 \%$ at the end of 2007) ${ }^{10}$ did not undermine the international confidence in the world's most important currency in this area of use. In 2007 it was used in more than $86 \%$ of transactions in the global foreign exchange market whereas the euro's share in that year amounted to $37 \%$ (see Table 5).

Since 1999 the use of the euro in the foreign exchange market turnover has increased by 7 percentage points, mainly at the expense of the Japanese yen. The share of the latter in those transactions declined from $20-23 \%$ in the years $1999-2001$ to approx. $16 \%$ at the end of 2007. The share of the pound sterling, on the other hand, which remained the fourth popular vehicle currency over the whole period of analysis, reported a slight improvement from $11 \%$ in 1999 to $15 \%$ at the end of 2007 .

The evaluation of the US dollar's and the euro's use by monetary authorities in indirect payments, i.e. as intervention currencies, is limited by the lack of suitable statistical data. 
Table 5. Currency distribution of reported foreign exchange market turnover in 1999-2007 ${ }^{\mathrm{a}}$

\begin{tabular}{|c|c|c|c|c|}
\hline \multirow{2}{*}{ Currency } & \multicolumn{4}{|c|}{ Year } \\
\hline & 1999 & 2001 & 2004 & 2007 \\
\hline US dollar & 87.3 & 90.3 & 88.7 & 86.3 \\
\hline Euro & 30.1 & 37.6 & 37.2 & 37.0 \\
\hline Yen & 20.2 & 22.7 & 20.3 & 16.5 \\
\hline British pound & 11.0 & 13.2 & 16.9 & 15.0 \\
\hline
\end{tabular}

The scale of this phenomenon can be, however, evaluated based on the analysis of the above-presented countries and their exchange rate regimes related to the currencies which either serve as a reference currency or comprise a reference currency basket. Among approx. 100 countries which have presented their various exchange rate regimes, monetary authorities of the majority of countries from both Americas and Asia use mainly the US dollar in their interventions to stabilise their own currencies. Monetary authorities of 40 countries, on the other hand, undertake their interventions in the euro. The latter group of countries includes mostly the non-euro area EU member states and the countries which are institutionally related to the commonwealth or its member states.

\section{The US dollar and the euro as means of accumulation}

The share of the US dollar and the euro in foreign exchange reserves held by central banks (in other words - the official foreign exchange reserves) crowns their use in the functions of the measure of value and legal tender. Central banks hold certain amounts of the global currencies which allow them to pay their debts in foreign trade and financial transactions with abroad on time. The structure of the official foreign exchange reserves held worldwide in the years 1979-2007 is presented in Table $6^{11}$. The data reveal substantial changes in that structure over the analysed period.

Although in 2007 the US dollar could boast the dominant share in the global official foreign exchange reserves (approx. 65\%), it lost its relevance significantly as compared to the late 1970s (fall of more than 10 percentage points). The introduction of the euro was the major factor undermining the role of the US dollar as a reserve currency. In 1999, shortly after its introduction, central banks held as much as $18 \%$ of their foreign exchange reserves in the euro. It was slightly more than the sum of shares of the reserves held in the preceding year in the German mark (13.8\%), French franc $(1.6 \%)$ and Dutch guilder $(0.3 \%)$ which were used as international currencies before the introduction of the euro ${ }^{12}$. The euro has become the 
second most important reserve currency, and its role from the beginning has been gradually increasing. In 2007 the share of this currency in the reserves held by central banks exceeded $26 \%$ to be more than 8 percentage points higher than in the year 1999 .

Table 6. The structure of the global official foreign exchange reserves

\begin{tabular}{|c|c|c|c|c|c|c|}
\hline Currency & 1979 & 1990 & 1999 & 2002 & 2005 & 2007 \\
\hline US dollar & 73.2 & 50.6 & 71.0 & 67.0 & 66.7 & 63.7 \\
\hline Euro & & & 17.9 & 23.9 & 24.2 & 26.2 \\
\hline Yen & 3.6 & 8.0 & 6.4 & 4.4 & 3.6 & 2.9 \\
\hline Pound sterling & 1.8 & 3.0 & 2.8 & 2.8 & 3.6 & 4.8 \\
\hline Swiss franc & 2.4 & 1.2 & 0.2 & 0.4 & 0.1 & 0.2 \\
\hline Other currencies & 19.0 & 37.2 & 1.7 & 1.5 & 1.8 & 2.2 \\
\hline $\begin{array}{l}\text { Total official } \\
\text { foreign exchange } \\
\text { reserves }\end{array}$ & 100.0 & 100.0 & 100.0 & 100.0 & 100.0 & 100.0 \\
\hline
\end{tabular}

Source: IMF Annual Reports.

The international role of the US dollar and the euro is not threatened by other currencies. Although the share of the pound sterling is slightly rising (to reach 4.7\% in 2007), but the yen's is significantly declining (to only $2.9 \%$ ), and the role of the Swiss franc is marginal $(0.2 \%)$. At present, the share of the three currencies is three times lower than the euro's.

The role of the US dollar and the euro as reserve currencies is also visible in the structure of foreign exchange reserves held by countries which related their national currencies to the euro and the US dollar. In the countries which use the euro as a reference value the share of that currency in their foreign exchange reserves was estimated at approx. $85 \%$ on average at the end of 2005 , whereas this figure for the US dollar as a reference currency exceeded $75 \%{ }^{13}$. It points to a significant impact of the foreign exchange regime on the structure of foreign exchange reserves. In the first group of countries the exchange rate fluctuations band is broader as compared to the fixed rate and for this reason less reserves are held in the euro as a reference value. In the second group, on the other hand, the band is narrower, hence the domination of the US dollar in the reserves held by central banks.

\section{Conclusions}

To sum up, the increasing relevance of the euro as a global currency over the relatively short period of the last several years does not imply it will dethrone the US dollar in the 
nearest future. The American currency will remain for a long time the leading currency in the global trade and financial markets, which is related to:

1) the inertia in market players' behaviours; they are reluctant to abandon their habits (e.g. to recognise the euro as a main invoicing currency in the exports of energy resources instead of the US dollar);

2) the historical role of the US dollar in the world economy after the World War II and a well-developed infrastructure in the international financial market with a history of nearly 70 years, which was based on the US dollar;

3) lower transactions costs related to the volume of the trade in commodities and financial transactions denominated in this currency;

4) lower political risk in the United States (there is no threat of the country's collapse whereas with regards to the euro area such a risk cannot be entirely excluded) ${ }^{14}$.

The scope of the functions performed by the US dollar may become, however, limited in favour of the euro since:

1) The euro area meets more and more conditions essential to issue the global currency. First and foremost, it is the world's biggest exporter (its share more than triples the US exports), its production of "domestic wealth" (GDP) is only slightly lower than in the United States, it guarantees low CPI and the freedom of trade. The euro common currency for the whole area - unites also the national markets into a common market whose integration is still developing and at present a little smaller than the potential of the US financial market (the size of the euro area financial market, measured with the total capitalisation of the stock exchange, debt securities and commercial banks' assets was estimated at approx. USD 52 billion in the euro area and USD 57 billion in the US) ${ }^{15}$, yet in the euro area this market is supervised by common regulations of national institutions. The lack of such a supervision in the US market has recently led to a financial crisis, which has revealed that the euro area economy as a whole is in many ways based on more solid foundations than the US economy (it has a significantly higher savings rate, a lower household debt ratio, and a moderate budget deficit).

2) Unlike the US, the euro area has been for many years a net creditor whereas the US - the world's biggest debtor. Since the beginning of our decade, the deficit in the current account of this country has been oscillating around the economic safety margin (recognised as $5 \%$ of GDP), and in 2006 reached as much $6.2 \%$ of GDP ${ }^{16}$. It 
may significantly limit the demand for the US dollar in the individual functions of a global currency since a more reliable currency is issued by the euro area. And the latter has generated a symbolic surplus of approx. $1 \%$ of GDP in its current account in the whole period of its existence.

3) Still higher fluctuations of the US dollar exchange rate against the euro, and an increasing depreciation of the American currency in particular are observed. The instability and decrease of the dollar's purchasing power may encourage central banks, especially in the countries which have accumulated substantial amounts of assets denominated in the US dollar (China, India, Japan, newly industrialised countries) to diversify the structure of their official foreign exchange reserves decreasing the share of the US dollar in favour of the euro. As Russia's and other oil exporters' experience in this area indicates, however, it is a slow process, more dependent on the change of habits (such as abandoning oil quotations in the international market in the US dollar or the US dollar invoicing) than central banks' activities aimed at the change in the structure of their reserve assets.

4) Contemporary problems of the US economy related to the financial crisis unquestionably undermine the role of the US dollar as an international currency. For the euro, however, it would be better if its importance was higher, yet not for this reason but in order to improve the competitiveness of the euro area economies. It cannot be expected, however, in a short time since it requires structural changes in the member states (e.g. public finance reform, more flexibility of the labour and services markets, development of both entrepreneurship in the society and innovativeness among enterprises, etc.).

\footnotetext{
Notes

${ }^{1}$ Oręziak (2003), (2001).

${ }^{2}$ Which means that the national currency of a given country is used as a common equivalent by business entities from different countries in both their mutual settlements in the world market and in internal settlements instead of their national currencies (for more see for instance: Nakonieczna-Kisiel (2007), p.210 and next).

${ }^{3}$ Oręziak (2001), p.3, Zabielski (2002), p.65.

${ }^{4}$ ECB (2007), Oręziak (2008), “Gazeta Wyborcza” of 8 December 2008.

${ }^{5}$ ECB (www.ecb.int).

${ }^{6}$ Oręziak (2008), p.21.

${ }^{7}$ IMF (2007), pp.9-10.
} 
${ }^{8}$ Euro... (2008).

${ }^{9}$ Biznes (2008).

${ }^{10}$ ECB (2008), p.73.

${ }^{11}$ It is the structure of foreign exchange reserves as one of four elements of the global official reserve assets. The other elements are: the IMF tranche, the SDR and gold.

12 Oręziak (2008), p.26.

${ }^{13}$ Ibidem, p. 27.

${ }^{14}$ Oręziak (2003), p.101.

${ }^{15}$ EMU (2008), p.219.

${ }^{16}$ World ... (2007, 2008).

\section{References}

Biznes chce daty wejścia do euro. (2008). Rzeczpospolita, 18.11.

ECB (www.ecb.int).

ECB Monthly Bulletin (2008). Frankfurt: January.

ECB review of the international role of the euro.(2007). www.ecb.int, June.

EMU at 10. Successes and Challenges 10 Years Economic and Monetary Union. (2008). Europen Economy, 2.

Euro, czyli kotwica bezpieczeństwa. (2008). Rzeczpospolita, 2.02.

IMF Annual Report. (2007). Washington.

Nakonieczna-Kisiel, H. (2007). Pieniądz światowy. In J. Dudziński, H. Nakonieczna-Kisiel (Eds.), Międzynarodowe stosunki gospodarcze. Szczecin: West Pomeranian Business School.

Oręziak, L. (2001). Główne waluty międzynarodowe. Bank i Kredyt, 9, Bankowe ABC, 76.

Oręziak, L. (2003). Kierunki zmian w funkcjonowaniu rynku finansowego Unii Europejskiej. Bank i Kredyt, 7.

Oręziak, L. (2008). Euro - pieniądz międzynarodowy. Bank i Kredyt, 1.

Zabielski, K. (2002). Finanse międzynarodowe. Warszawa: PWN.

World Economic Outlook Database. (2007, 2008). IMF, April. 